\title{
Knowledge, Attitude and Practices (KAP) about biomedical waste management among hospital staff-A crossectional study in a tertiary care hospital, Andhra Pradesh, India
}

\author{
Lavanya K. M. ${ }^{1}$, Padmavati Majhi²,* \\ Associate Professor, Dept. of Community Medicine, GSL Medical College, Andhra Pradesh, India
}

*Corresponding Author:

Email: dr.padmavatimajhi@yahoo.com

\begin{abstract}
Introduction: Hospitals produce waste, which is increasing over the years in its amount and type. Hospital waste is a special category of waste which needs to be handled appropriately with precautions because in addition to the risk for patients and personnel who handle them, they also pose a threat to public health and environment.

Objectives: To assess Knowledge, Attitude and Practices about Biomedical waste management among staff of a tertiary care hospital, Andhra Pradesh.

Materials and Methods: A questionnaire with multiple choice questions type of answers to assess the Knowledge, Attitude and Practices of Biomedical waste management was given to the 3 categories of hospital staff in selected high risk areas like operation theatre, laboratories, medical ward and surgical ward, casualty, outpatient departments. The staff included Nurses including O.T. Staff, Sanitary Staff and Laboratory Staff. The answers were analyzed using Percentagesand Chi-square test.

Results: The knowledge was significantly better among the nurses while it was poor among the sanitary staff.

Conclusions: It is important to improve the knowledge regarding Bio-medical waste among all levels of hospital staff because this forms the foundation for effective and proper Bio-Medical waste management.
\end{abstract}

Keywords: Bio-medical waste management, KAP, Tertiary care hospital, Andhra Pradesh.

\section{Introduction}

Healthcare institutions are service oriented establishments that provide medical care facilities comprising of observational, diagnostic, research and therapeutic and rehabilitative services. These facilities are among the largest generators of solid waste on a per capita basis.Hospitals produce waste, which is increasing over the years in its amount and type. Hospital waste has become a prime concern due to its multidimensional ramifications as a risk factor which needs to be handled appropriately with precautions because in addition to the risk for patients and personnel who handle them, they also pose a threat to public health and environment.

According to WHO (2000), around $85 \%$ of hospital waste is non-hazardous, $10 \%$ infective and remaining $5 \%$ non- infective but hazardous. ${ }^{1}$ With a rapid increase in the number of hospitals, clinics and laboratories in the country, the generation of health care waste has been increasing considerably. The quantity of biomedical waste generated will vary depending on the hospital policies and practices and the type of care being provided. The data available from developed countries indicate a range from 1 to $5 \mathrm{Kg} / \mathrm{bed} / \mathrm{day}$, with substantial intercountry and interspeciality differences. Meager data from developing countries indicates that the range is essentially similar but the figures are lower i.e. 1 to $2 \mathrm{Kg} / \mathrm{bed} /$ day. ${ }^{2}$ There are not many national level studies on the quantum of waste generated per bed per day. However, the average quantity of hospital waste produced in India has been shown by various authors to the extent of 1.5 to $2.2 \mathrm{Kg}$ per bed per day. ${ }^{3}$ Bio - medical Waste (Management and Handling) Rule 1998 prescribed by the Ministry of Environment and Forests, Government of India, came into force on $8^{\text {th }}$ July 1998. This rule applies to those who generate, collect, receive, store, dispose, treat or handle biomedical waste in any manner. This Act is now superceded by Bio-Medical Waste Management Rules 2016, which came into force on $28^{\text {th }}$ March $2016 .{ }^{4}$ The current study was taken to reveal the important issues related to the above subject in a tertiary care hospital, Rajahmundry, since very few studies are available about the same.

\section{Aims and Objectives}

1. To assess Knowledge and Attitude regarding biomedical waste management among hospital staff in a tertiary care hospital, Rajahmundry.

2. To assess the present practices of biomedical waste management

3. To provide recommendations for proper biomedical waste management.

\section{Materials and Methods}

It was a Cross-sectional study conducted in a 750 bedded tertiary care hospital of Rajahmundry, with a staff capacity of 860 including doctors, postgraduates, house surgeons, nursing staff, lab technicians and sanitary staff. The hospital caters to the services in medical, surgical, 0orthopaedic, neurologic, 
nephrologic, anaesthetic and associated diagnostic departments.

Data was collected using a standard questionnaire administered to the key informants or healthcare staff. The questionnaire included questions regarding awareness about Bio-Medical WasteManagement Rule 2016, categories of biomedical waste, waste segregation, collection, labeling, transport and disposal, financial and personal resources. The views and suggestions of working personnel over existing conditions/methods of biomedical waste management in the hospitals were recorded. The information obtained was later confirmed by means of direct observations, especially about the practices. Study participants included 3 categories of staff i.e Nurses, Lab technicians and Sanitary staff, since they handled the biomedical waste daily. The sampling frame included 1030 staff totally of which we included $20 \%$ of the subjects in each category by probability proportional to size sampling, making a sample size of 206 and subjects were selected by systematic random sampling.

The study period was 3 months from Aug 2017 to Oct 2017

The obtained data was tabulated in the Microsoft excel 2007, double checked for errors and analyzed using Epi info 3.5 .3

\section{Observations and Results}

Out of 206 study subjects, 62(30.1\%) were males and $144(69.9 \%)$ were females; $104(50.5 \%)$ were nurses, $18(8.7 \%)$ were lab technicians and $84(40.8 \%)$ were housekeeping staff.

Table 1: Total number of staff as per cadre

\begin{tabular}{|c|l|c|c|}
\hline S. No. & Number of staff & Number & Percentage \\
\hline 1. & Nursing staff & 104 & 50.5 \\
\hline 2. & Laboratory staff & 18 & 8.7 \\
\hline 3. & Housekeeping staff & 84 & 40.8 \\
\hline & Total & 206 & 100.0 \\
\hline
\end{tabular}

\section{Knowledge about Bio-medical Waste}

Totally $118(57.3 \%)$ study subjects knew about BMW and its composition correctly. About sources of BMW, knowledge among the nurses was $81(77.9 \%)$, among the technicians $12(66.7 \%)$ and among the housekeepers 25(29.8\%). Knowledge about hazards to health was correct in $132(64.1 \%)$ of the study group. It was 95(91.3\%) among nurses, $12(66.7 \%)$ among Lab technicians and $25(29.8 \%)$ among housekeepers. Hand washing as the best personal protective measure was known to $128(62.1 \%)$ subjects with knowledge among nurses being89(85.6\%), among lab technicians it was 9 (50\%) and among housekeeping staff it was 30(35.7\%). Totally 126 $(61.2 \%)$ study subjects knew about segregation at the point of generation, it was57 (54.8\%) among nurses, 8 (44.4\%) among technicians and $61(72.6 \%)$ among the housekeepers.Totally $106(51.5 \%)$ knew about the color coded bins used for various categories of BMW.Knowledge among nurses was 61(58.7\%), among lab technicians it was $8(44.4 \%)$ and among housekeeping staff it was $37(44.0 \%)$. (Table 2)

Table 2: Knowledge about Bio-medical Waste among staff

\begin{tabular}{|l|c|c|c|c|}
\hline \multicolumn{1}{|c|}{ Parameter } & $\begin{array}{c}\text { Nurses } \\
(\mathbf{n = 1 0 4})\end{array}$ & $\begin{array}{c}\text { Lab } \\
\text { technicians } \\
(\mathbf{n = 1 8})\end{array}$ & $\begin{array}{c}\text { Housekeeping } \\
\text { staff } \\
(\mathbf{n = 8 4})\end{array}$ & $\begin{array}{c}\text { Chi-square } \\
\text { and } \\
\text { P value }\end{array}$ \\
\hline $\begin{array}{l}\text { Bio-medical waste and } \\
\text { its Composition }\end{array}$ & $76(73.07)$ & $15(83.33)$ & $27(32.14)$ & $\begin{array}{c}37.29 \\
\mathrm{P} 0.000\end{array}$ \\
\hline $\begin{array}{l}\text { Sources of Bio-medical } \\
\text { waste }\end{array}$ & $81(77.9)$ & $12(66.7)$ & $25(29.8)$ & 44.69 \\
\hline $\begin{array}{l}\text { Hazards of Bio-medical } \\
\text { waste to health }\end{array}$ & $95(91.3)$ & $12(66.7)$ & $25(29.8)$ & 76.000 \\
\hline $\begin{array}{l}\text { Handwashing as the } \\
\text { best personal protective } \\
\text { measure }\end{array}$ & $89(85.6)$ & $09(50.0)$ & $30(35.7)$ & $\mathrm{P} 0.000$ \\
\hline $\begin{array}{l}\text { About segregation at } \\
\text { the point of generation }\end{array}$ & $57(54.8)$ & $08(44.4)$ & $61(72.6)$ & $\begin{array}{c}50.34 \\
\mathrm{P} 0.000\end{array}$ \\
\hline $\begin{array}{l}\text { Color coded bins used } \\
\text { for various categories }\end{array}$ & $61(58.7)$ & $08(44.4)$ & $37(44.0)$ & 8.528 \\
\hline
\end{tabular}

\section{Attitude about Bio-medical Waste}

The attitude of the study subjects toward BMW management as a part of their job was positive in $149(72.3 \%)$ i.e. in $86(82.7 \%)$ of the nurses, $14(77.8 \%)$ technicians and $49(58.3 \%)$ housekeepers. All the waste generated in the hospital is infectious was said by $134(65 \%)$ subjects with $54(51.9 \%)$ among nurses, 11(61.1\%) among technicians 
and $69(82.1 \%)$ among housekeepers. Only 143(69.4\%) said hospital policy for BMW management is needed with $90(86.5 \%)$ among nurses, 14(77.8\%) among technicians and 39(46.4\%) among housekeepers. Training about BMW management is necessary according to $148(71.8 \%)$ subjects with $80(76.9 \%)$ among nurses, $14(77.8 \%)$ among technicians and 54(64.3\%) among housekeepers. Positive opinion about the necessity of periodical medical examination for staff was seen in 171(83\%) staff with $99(95.2 \%)$ among nurses, 14(77.8\%) among technicians and $58(69 \%)$ among housekeepers. (Table 3)

Table 3 Attitude about Biomedical Waste among staff

\begin{tabular}{|c|c|c|c|c|}
\hline Parameter & $\begin{array}{l}\text { Nurses } \\
(n=104)\end{array}$ & $\begin{array}{c}\text { Lab } \\
\text { technicians } \\
(n=18)\end{array}$ & $\begin{array}{c}\text { Housekeeping } \\
\text { staff } \\
(\mathbf{n}=\mathbf{8 4})\end{array}$ & $\begin{array}{c}\text { Chi-square } \\
\text { and } \\
P \text { value }\end{array}$ \\
\hline $\begin{array}{l}\text { BMW Management is a part of } \\
\text { job }\end{array}$ & $86(82.7)$ & $14(77.8)$ & $49(58.3)$ & $\begin{array}{r}14.069 \\
\text { P } 0.001 \\
\end{array}$ \\
\hline $\begin{array}{l}\text { All waste generated in hospital } \\
\text { is infectious }\end{array}$ & $54(51.9)$ & $11(61.1)$ & $69(82.1)$ & $\begin{array}{l}18.800 \\
\mathrm{P} 0.000 \\
\end{array}$ \\
\hline $\begin{array}{l}\text { Hospital policy for BMW } \\
\text { management is needed }\end{array}$ & $90(86.5)$ & $14(77.8)$ & $39(46.4)$ & $\begin{array}{l}35.863 \\
\mathrm{P} 0.000 \\
\end{array}$ \\
\hline $\begin{array}{l}\text { Training about BMW } \\
\text { management is necessary }\end{array}$ & $80(76.9)$ & $14(77.8)$ & $54(64.3)$ & $\begin{array}{c}4.012 \\
\text { P } 0.135\end{array}$ \\
\hline $\begin{array}{l}\text { Periodical medical examination } \\
\text { is necessary }\end{array}$ & 99 (95.2) & $14(77.8)$ & $58(69.0)$ & $\begin{array}{l}22.902 \\
\text { P } 0.000\end{array}$ \\
\hline
\end{tabular}

\section{Practices about Bio-medical Waste}

Personal protective measures while handling waste was used by $148(71.8 \%)$ subjects with $90(86.5 \%)$ nurses, 7(38.9\%) technicians and 51(60.7\%) housekeepers. Hand-washing after handling waste was practiced by $142(68.9 \%)$ subjects which was seen in $93(89.4 \%)$ nurses, $15(83.3 \%)$ technicians and 34(40.5\%) housekeepers. Subjects who were immunized with Tetanus toxoid were137(66.5\%), i.e. 89(85.6\%) of nurses, 13(72.2\%) technicians and 35(41.7\%) housekeepers. Subjects who were immunized with Hepatitis B vaccine were 109(52.9\%), i.e. $69(66.3 \%)$ of nurses, $11(61.1 \%)$ technicians and 29(34.5\%) housekeepers. Out of 206 subjects, only 109(52.9\%) had received training about BMW management. Majority of the nurses 67(64.4\%) had undergone training while it was lower in technicians $10(55.5 \%)$ and housekeepers 32(38.1\%). Accident reporting was practiced by $103(50 \%)$ subjects with $66(63.5 \%)$ among nurses, $11(61.1 \%)$ among technicians and 26(31\%) among housekeepers. (Table 4)

Table 4: Practices about Biomedical Waste among staff

\begin{tabular}{|l|c|c|c|c|}
\hline \multicolumn{1}{|c|}{ Parameter } & $\begin{array}{c}\text { Nurses } \\
(\mathbf{n = 1 0 4})\end{array}$ & $\begin{array}{c}\text { Lab } \\
\text { technicians } \\
(\mathbf{n = 1 8})\end{array}$ & $\begin{array}{c}\text { Housekeeping } \\
\text { staff } \\
(\mathbf{n = 8 4})\end{array}$ & $\begin{array}{c}\text { Chi- } \\
\text { square and } \\
\text { P value }\end{array}$ \\
\hline $\begin{array}{l}\text { se of personal protective } \\
\text { measures }\end{array}$ & $90(86.5)$ & $07(38.9)$ & $51(60.7)$ & $\begin{array}{c}5.910 \\
\text { P } 0.000\end{array}$ \\
\hline $\begin{array}{l}\text { And washing after } \\
\text { handling waste }\end{array}$ & $93(89.4)$ & $15(83.3)$ & $34(40.5)$ & 53.894 \\
\hline $\begin{array}{l}\text { mmunized with TT } \\
\text { mmunized with }\end{array}$ & $69(85.6)$ & $13(72.2)$ & $35(41.7)$ & $\begin{array}{c}40.000 \\
\text { P } 0.000\end{array}$ \\
\hline $\begin{array}{l}\text { Hepatitis- B } \\
\text { maining about BMW }\end{array}$ & $67(64.4)$ & $10(55.5)$ & $32(38.1)$ & $\begin{array}{c}19.519 \\
\text { P } 0.000\end{array}$ \\
\hline ccident reporting & $66(63.5)$ & $11(61.1)$ & $26(31.0)$ & $\begin{array}{c}12.983 \\
\text { P } 0.002\end{array}$ \\
\hline
\end{tabular}

Knowledge about the sources of Bio-medical Waste, hazards, hand-washing as the best personal protective measure and color coded bins used for various categories is significantly better in nurses while the knowledge about segregation at the point of generation is significantly better in housekeeping staff and knowledge about definition and composition of Bio-medical Waste is significantly better among lab technicians compared to other staff. The overall positive attitude towards Bio-medical Waste management is significantly higher in the technical and nursing staff. In all aspects, the practice of Bio-medical Waste management is significantly better among nurses compared to others. 


\section{Discussion}

In this study, nurses knew significantly better about sources of BMW than the technical and housekeeping staff $\left(\mathrm{P}<0.000, \mathrm{x}^{2}=44.687\right)$ consistent with a study in a tertiary hospital by Saini $\mathrm{S}$ et. al, ${ }^{5}$ which showed that $85 \%$ nurses, $14 \%$ housekeeping and $12 \%$ technical staff had knowledge about BMW. In this study, knowledge about hazards to health was significantly better in nurses than in technical and housekeeping staff $\left(\mathrm{P}=0.000, \mathrm{x}^{2}=76.621\right)$ In Gujarat, it was found that doctors were aware of risk of health hazards, whereas auxiliary staff (ward boys, aayabens, sweepers) had very poor knowledge about it. ${ }^{6}$ It was also found in this study that knowledge about segregation at the point of generation was significantly better in the Housekeeping staff compared to others $\left(\mathrm{P}=0.014, \mathrm{x}^{2}=8.528\right)$. Knowledge about colour coded bins was significantly better among nurses while it was almost similar in technical and housekeeping staff and this is consistent with the findings of Mathur et. al. ${ }^{7}$ It was also found that the nurses had significantly positive attitude towards BMW management as a part of their job, when compared to the technicians and the housekeeping staff $(\mathrm{x} 2=14.069, \mathrm{P}=0.001)$. All the waste generated in the hospital is infectious was felt mostly by housekeepers $(82.1 \%)$, showing a statistical significant difference compared to other staff. Only 143(69.4\%) said hospital policy for BMW management is needed with 90 (86.5\%) among nurses, 14(77.8\%) among technicians and 39(46.4\%) among housekeepers. Training about BMW management is necessary according to $148(71.8 \%)$ subjects with $80(76.9 \%)$ among nurses, 14(77.8\%) among technicians and 54(64.3\%) among housekeepers. Positive opinion about the necessity of periodical medical examination for staff was seen in 171(83\%) staff with 99 (95.2\%) among nurses, 14(77.8\%) among technicians and 58 (69\%) among housekeeping staff.The overall positive attitude towards BMW management was seen in $92.3 \%$ of nurses and $77.4 \%$ of the housekeeping staff with statistically significant difference ( $\mathrm{x} 2=12.066, \mathrm{P}=0.002)$, similar to a study by Pandit NB et. al, ${ }^{6}$ which found that $98 \%$ of the nurses and $79 \%$ of the housekeeping staff had a positive attitude. While $100 \%$ of the technical staff had positive attitude towards BMW management in our study, only $59 \%$ of the technical staff had a positive attitude in the study by Pandit NB et. al. ${ }^{6}$

Regarding BMW practices, it was found that the nurses practiced BMW management better than the technical and housekeeping staff and a significant difference was found $(\mathrm{x} 2=53.894, \mathrm{P}=0.000)$. In this study $95.2 \%$ of the nurses, $72.2 \%$ of the technical staff and $48.8 \%$ of the housekeeping staff practiced BMW management correctly. In a tertiary hospital study by Saini et. al, ${ }^{5}$ it was found that $100 \%$ nurses, $70 \%$ of the housekeeping staff and only $47 \%$ of the technical staff practiced BMW management. In this study, it was also found that the non-infectious waste was collected separately in different containers and treated as general waste. At Jhansi it was found that the process of segregation, collection, transport, storage and final disposal of infectious waste was done in compliance with the standard procedures. In a study by Patil GV, Pokhrel $K,{ }^{8}$ it was also found that the non-infectious waste was collected separately in different containers and treated as general waste.Singh $\mathrm{K}$ et. $\mathrm{al},{ }^{9}$ in Chandigarh revealed that the medical establishments in the rural area and smaller ones in the urban area dispose off their biomedical waste along with municipal solid waste and no waste management system exists.. In one of the district in Gujarat, there was no effective waste segregation, collection, transportation and disposal system at any hospital. ${ }^{5}$ Rasheed $\mathrm{S}$ et. $\mathrm{al}^{10}$ in his study in Karachi revealed that $25 \%$ hospitals were segregating sharps, pathological waste, chemical, infectious, pharmaceutical and pressurized containers at source. Personal protective measures while handling waste was used by $148(71.8 \%)$ subjects with significantly better use among nurses, (86.5\%). Waste handlers in $76.47 \%$ of the hospitals used no protective gear as found in a survey carried out by the department of Community Medicine, M.S. Ramaiah Medical College in Bangalore. ${ }^{11}$ Another study also revealed that the safety practices adopted by the sanitation staff for collection of Bio-Medical Waste are rudimentary and only 30\% sweepers were using gloves while managing wastes, whereas apron, long-boots, eye-shields were worn by none. ${ }^{12}$ Accident reporting was practiced only by $50 \%$ of the subjects in this study and it was significantly more among nurses $(63.5 \%)$. This is similar to a study by Shalini Sharma, ${ }^{13}$ who also reported that accident reporting was poor among all cadre of staff and no one reported it to the higher authorities.

\section{Conclusions}

The staff lacked the required knowledge about BMW management. A positive attitude was found to improve the current situation in BMW management. The nurses were having better knowledge and attitude, and also practiced BMW management better than the housekeeping and technical staff.

\section{Recommendations}

Regular training of nursing, technical and housekeeping staff should be done by more and more training sessions and practical demonstrations and system of monitoring should be evolved. Nursing staff who are correctly practicing BMW management should be involved as role models for others. Rewardsfor the hospitals and staff practicing best BMW management to be implemented at the state level. A chapter on BMW management to be included in the curriculum of medical, dental, nursing and technical staff. 


\section{Limitations of the Study}

Study was done on small sample and only 3 cadre of staff. More studies to be conducted on doctors, students as well as patients who are all at risk of exposure to BMW. Only one government teaching hospital was taken, however such studies are required to be conducted in all the hospitals.

\section{References}

1. Management of Waste from hospitals and other health care establishments. Euro Report and Studies 1985; 1(97):1-61.

2. Grovers PD. Management of Hospital Wastes - an overview. Proceedings of national workshop on management of hospital waste, $1998 \mathrm{Apr} 16^{\text {th }}$ to $18^{\text {th }}$ : Jaipur, IIRD and Shristi,1998.

3. Pandit NA, Tabish SA, Qadri GJ, Ajaz Mustafa. 'Biomedical Waste Management in a large teaching hospital', JK Practitioner Vol.14, No.1, Jan - March 2007; (pp 57-59).

4. Government of India (2016). Ministry of Environment, Forest and Climate Change, Notification published in The Gazette of India, Bio-Medical Waste Management Rule 2016.

5. Saini S, Nagarajan SS, Sarma RK. KAP of BMW Management amongst staff of a tertiary level hospital in India. J AcadHosp Admin. 2005;17:1-12.s

6. Pandit NB, Mehta HK, Kartha GP, Choudhary SK. Management of biomedical waste: Awareness and practices in a district of Gujarat. Indian J Public Health. 2005;49:245-7. [PubMed]

7. Vanesh Mathur, S.Dwivedi, MA Hassan, RP.Misra. Knowledge, Attitude and Practices (KAP) about Biomedical Waste Management among healthcare personnel: A Cross sectional study, Indian Journal of Community Medicine, April 011; vol 36, issue 2.

8. Patil GV, Pokhrel K. Biomedical solid waste management in an Indian hospital: A case study. Waste Manag. 2005;25:592-9. [PubMed]

9. Singh K, Arora SK, Dhadwal PJ, Singla A, John S. Biomedical waste management in the U.T., Chandigarh. J Environ Sci Eng. 2004;46:55-60. [PubMed]

10. Rasheed S, Iqbal S, Baig LA, Mufti K. Hospital waste management in the teaching hospitals of Karachi. J Pak Med Assoc. 2005;55:192-5. [PubMed]

11. Health Care Waste Disposal - department of Community Medicine, M.S.Ramaiah Medical College, Bangalore 560054, 1997.

12. Srivastav Shalini, Mahajan Harsh, Mathur B P. Evaluation of Bio-medical Waste Management Practices in a Government Medical College and Hospital. National Journal of Community Medicine; Vol 3, Issue 1: JanMarch 2012.

13. Shalini Sharma and S.V.S.Chauhan. Assessment of biomedical waste management in three apex Government hospitals of Agra. Journal of Environmental Biology: March 2008, 29(2) 159-162 (2008). 